\title{
Impact of Long-Term Conventional Cropping Practices on Some Soil Quality Indicators at Ethiopian Wonji Sugarcane Plantation
}

\section{Alemayehu Dengia ${ }^{1 *}$ and Egbert Lantinga ${ }^{2}$}

${ }^{1}$ Sugar Corporation, Research and Training, Wonji Research Center, Wonji-Ethiopia, Ethiopia

${ }^{2}$ Department of Plant Sciences, Biological Farming Systems Group, Wageningen University, Radix West, 2nd floor, Droevendaalsesteeg, 16708 PB Wageningen, The Netherlands

\begin{abstract}
Over the last 50 years, the sugarcane yield in Wonji plantation has declined by about $40 \%$. Perhaps one of the possible causes for the decline is soil degradation. Thus, the major soil quality indicators were evaluated for the extent of change that might occur due to long-term conventional cropping practices. To that end bio-sequential soil sampling was performed by collecting soil samples from adjacent virgin and cultivated lands of Wonji sugar cane plantation. The samples were analyzed and compared for major soil properties. The result showed that the SOM contents of cultivated land were $53 \%$ and $34 \%$ lower than the virgin land at $0 \mathrm{~cm}-30 \mathrm{~cm}$ and $30-60 \mathrm{~cm}$ depths, respectively. Total N, P Olsen, exchangeable $\mathrm{K}$ and soil EC of the cultivated land were also $56 \%, 84 \%, 86 \%$ and $54 \%$ lower than the virgin land at $0 \mathrm{~cm}-30 \mathrm{~cm}$. The differences were also significant at $30 \mathrm{~cm}-60 \mathrm{~cm}$. There was no significant change in soil $\mathrm{pH}$ at both depths. In general long-term conventional cropping practices depleted the SOM, total $\mathrm{N}, \mathrm{P}$ Olsen and exchangeable $\mathrm{K}$. However, $\mathrm{pH}$ and $\mathrm{EC}$ were in the optimum range that soil acidity, salinity and alkalinity were not a problem. As the soil type of the plantation is heavy clay, particularly, the degradation in SOM content might cause the yield decline. In order to fully identify, understand and manage the problems of soil quality deterioration further study is necessary.
\end{abstract}

Keywords: SOM; Conventional cropping; Yield decline; Soil degradation; Total N, P; Olsen; Exchangeable K; EC; pH 1

\section{Introduction}

Sugar cane production is one of the largest and most important agro-industries around the world in general and in developing countries in particular. Nowadays, sugar cane is considered as a Dollar Earner for tropical countries due to its immense potential to generate hard currency [1]. Therefore, achieving sustainable cane production is an increasingly important goal in recent years so as to exploit this potential. However, in several sugar cane producing countries around the world, decline in sugar cane yield appears to be the major preoccupation of the agroindustry [2-4]. Likewise, sugar cane yield decline is currently becoming the major area of attention in the Ethiopian sugar cane plantations. Although, Ethiopia is one of the countries with the highest sugar cane yield in the world $[5,6]$ the yield has been declining already for many years. For instance over the last 50 years, the cane yield per ha in Wonji sugar cane plantation has dropped by about $40 \%$ (Figure 1). Thus, the future viability of the agro-industry will be doubtful unless the yield decline could be stopped. Therefore, identifying and understanding the cause of the yield decline has paramount importance to design and recommend appropriate management strategies. This is particularly essential in view of the current Ethiopian government ambitious plan to augment the sugar production capacity of the country.

The cause for sugar cane yield decline is a complex issue, as it results from a number of factors. According to De Wit [7] actual crop yield generally depend on growth-defining, growth-limiting and growthreducing factors. In monoculture sugarcane farming, where long-term conventional cropping practices are widely adopted, these factors may not be sustained at the optimum level for cane growth. Particularly, upon cultivation the deterioration of soil quality is inevitable which may lead to soil degradation and consequently yield decline.

A soil with a high quality is productive and has a stable yield [8] whereas its degradation adversely affects the agronomic productivity [9]. Similarly, in sugar cane plantations, soil degradation was found to be one of the major contributors for yield decline $[4,10]$. The losses in soil production capacity of a sugar cane field could be mainly ascribed to long-term monoculture, uncontrolled traffic from heavy machineries, excessive tillage before planting [4] pre-harvest cane burning [11], inappropriate irrigation and drainage [12] and excessive utilization of agrochemicals [13]. These conventional cropping practices lead to change in soil biological, physical and chemical properties with concomitant decline in cane yield [13]. Similarly the aforementioned practices were also adopted in Wonji plantation over the last fifty years and May resulted in soil degradation.

Therefore, the objective of this research is to evaluate the major soil quality indicators of Wonji sugar cane plantation so as to understand the possible existence and extent of soil degradation. The approach taken was to collect soil samples from virgin and cultivated lands biosequential soil sampling of the sugar cane plantation and to evaluate the differences in the major soil quality indicators soil organic matter, total $\mathrm{N}$, available $\mathrm{P}$, exchangeable $\mathrm{K}, \mathrm{EC}$ and $\mathrm{pH}$.

\section{Materials and Methods}

\section{Site description}

The study was conducted between September 2009 and February 2010 in Wonji sugar estate $\left(8^{\circ} 31^{\prime} \mathrm{N}\right.$ and $\left.39^{\circ} 12^{\prime} \mathrm{E}\right)$, which is $110 \mathrm{~km}$ southeast of Addis Ababa (Figure 2). The site is located at an altitude of 1540 meter above sea level. The average annual rainfall is $807 \mathrm{~mm}$.

${ }^{*}$ Corresponding author: Alemayehu Dengia, Sugar Corporation, Research and Training, Wonji Research Center, Wonji-Ethiopia, Ethiopia, Tel: +251222201809; E-mail: alexdengia@yahoo.com

Received March 21, 2016; Accepted May 02, 2016; Published May 09, 2016

Citation: Alemayehu D, Lantinga E (2016) Impact of Long-Term Conventional Cropping Practices on Some Soil Quality Indicators at Ethiopian Wonji Sugarcane Plantation. Adv Crop Sci Tech 4: 224. doi:10.4172/2329-8863.1000224

Copyright: (c) 2016 Alemayehu D, et al. This is an open-access article distributed under the terms of the Creative Commons Attribution License, which permits unrestricted use, distribution, and reproduction in any medium, provided the original author and source are credited. 


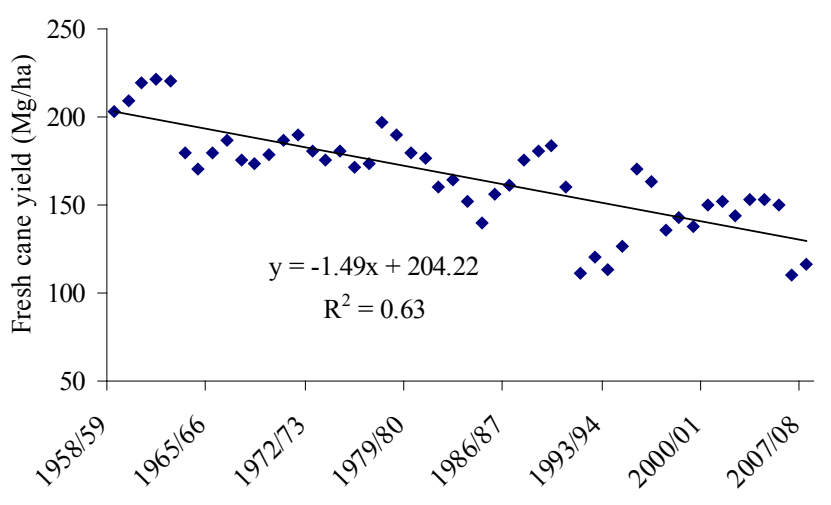

Years of cultivation

Figure 1: The yields of sugar cane over 50 years production period [19582008] of the Ethiopian Wonji Sugar cane plantation.

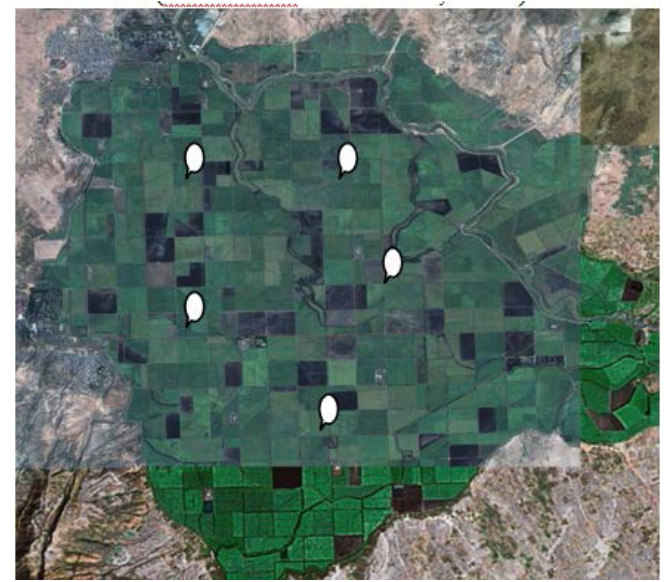

Figure 2: Field map of Wonji plantation: sites marked with white dots are the locations of bio-sequential soil sampling.

while average daily minimum and maximum temperatures are $14.3^{\circ} \mathrm{C}$ and $27.6^{\circ} \mathrm{C}$, respectively. The soils of the study area are predominantly heavy clay. The slope of the land is very gentile and regular. Before the establishment of the estate, the Wonji plain was a sparsely populated area due to flood and malaria hazards. In 1950s the land was given to the Dutch company, HVA, for establishment of a sugar estate and in 1954 sugar production was started [14].

\section{Soil sampling}

There are two common methods of studying changes in soil properties of farmlands under long-term cultivation: chronosequential sampling or Type I data and bio-sequential sampling or Type II data [15]. The former is used to monitor soil dynamics over time at the same site while in the latter case soils of cultivated and uncultivated lands are simultaneously sampled and compared. In this study, bio-sequential soil sampling method was used and the underlying assumption was that the soils from adjacent virgin and cultivated land were originally similar and that current differences in the soil physicochemical properties are due to cultivation [15].

In order to collect the required samples, five representative sites were randmly selected from the 7000 ha of Wonji plantation fields (Figure 2). The virgin lands were located near plantation villages of the sugar estate. Each village has about one ha virgin land which was intended as entertainment place for the villages' residents since the commencement of sugar cane cultivation. Thus, the selected virgin lands were assumed to represent the original soil conditions of the site. Corresponding soil samples were also taken from the cultivated fields, near each of the selected virgin lands.

\section{Method of soil analysis}

The soil samples were analyzed in the research directorate of Ethiopian sugar development agency laboratory located in Wonji sugar estate.

Soil $\mathrm{pH}$ and EC were measured in a 1:2.5 soil water suspension by a glass electrode $\mathrm{pH}$ meter and $\mathrm{EC}$ meter, respectively. Total soil $\mathrm{N}$ was measured following Kjeldahl procedure which involved digestion of the samples in concentrated $\mathrm{H}_{2} \mathrm{SO}_{4}$ with a catalyst mixture to raise the boiling temperature and to promote the conversion from organic- $\mathrm{N}$ to ammonium-N. Ammonium-N from the digest was obtained by steam distillation, using excess $\mathrm{NaOH}$ to raise the $\mathrm{pH}$. The distillate was collected in saturated $\mathrm{H}_{3} \mathrm{BO}_{3}$ and then titrated with diluted $\mathrm{H}_{2} \mathrm{SO}_{4}$ to $\mathrm{pH} 5.0$ [16] Organic carbon was determined by WalkleyBlack procedure which involves reduction of potassium dichromate by organic carbon compounds and subsequent determination of the unreduced dichromate by oxidation-reduction titration with ferrous ammonium sulphate. Finally, the amount of organic matter was determined according to the approximation: soil organic carbon $\times$ $1.72=\mathrm{SOM}$ [17]. Available soil $\mathrm{P}$ was determined by sodium bicarbonate method where $\mathrm{P}$ was extracted with $0.5 \mathrm{M}$ sodium bicarbonate and measured calorimetrically [18]. Exchangeable $\mathrm{K}$ was determined by flame photometer after the samples were extracted with Morgan's solution [19].

\section{Data analysis}

The data were analyzed by paired samples t-test analyses at $1 \%$ probability level using Genstat software statistical packages, $12^{\text {th }}$ edition. Mean comparisons were also performed.

\section{Results and Discussion}

SOM, total N, P Olsen, exchangeable K and soil EC of the cultivated land were much lower than the virgin land at both $0 \mathrm{~cm}-30 \mathrm{~cm}$ and 30 $\mathrm{cm}-60 \mathrm{~cm}$ soil depths $(P<0.01)$. Nevertheless, no significant difference was observed in soil $\mathrm{pH}$ at both depths.

\section{Soil Organic Matter (SOM)}

The SOM content of the cultivated land was $53 \%$ and $34 \%$ lower than the virgin land at $0 \mathrm{~cm}-30 \mathrm{~cm}$ and $30 \mathrm{~cm}-60 \mathrm{~cm}$ depth, respectively (Figure 3). Thus, the SOM of the cultivated land was depleted considerably suggesting that long-term conventional cropping practices have degraded the soil. In agreement with the current result, several data from other long-term cropping systems trials also showed a decline in SOM and deterioration of soil quality under continuous cultivation as compared to native vegetation [20].

The observed differences between SOM contents of the cultivated and virgin land in Wonji sugar cane plantation at $0-30 \mathrm{~cm}$ depth was comparable with the differences observed in Philippines and Papua New Guinea. Alaban et al. [21] in Philippines and Hartemink et al. [22] in Papua New Guinea found the differences of $26 \%$ and $42 \%$ SOM, respectively, over a 20 years period of sugar cane cultivation. In China, Liu et al. reported that during 5, 14 and 50 year cultivation periods soil organic carbon losses were $17 \%, 28 \%$ and $55 \%$, respectively. Contrastingly, Naranjo et al. [23] in Mexico and Bramley et al. [10] in 


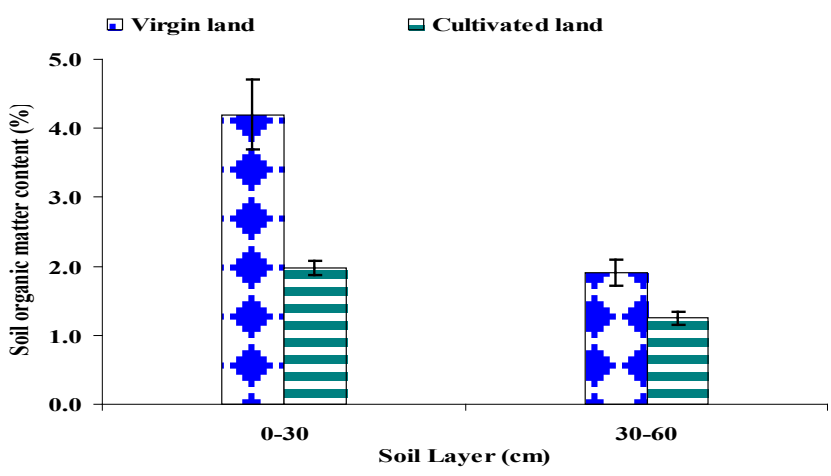

Figure 3: SOM content [\%] at Wonji sugar cane plantation sampled from land areas under conventional cropping practices for 50 years and adjacent lands that were never cultivated [virgin] at $0 \mathrm{~cm}-30 \mathrm{~cm}$ and $30 \mathrm{~cm}-60 \mathrm{~cm}$ depths [means of five sampling sites]. Means of virgin and cultivated lands are significantly different at $\mathrm{P}<0.01$. Vertical bars indicate \pm SEM [standard error of mean].

northern Australia found non-significant differences in SOM contents after 30 and 20 years of sugar cane cultivation, respectively. This could be explained in the latter case by adoption of recommended practices which have the potential to sustain or increase SOM contents and sugar cane yield $[19,23]$. These practices mainly include integrated management of nutrients and sugar cane trash retention.

The absence of appropriate practices in the Wonji sugar estate played in all probability a significant role for the substantial differences observed in SOM contents of the tow soil types. For instance due to pre-harvest cane burning, about 14 ton/ha organic matter is lost up on harvesting 120 ton/ha sugar cane [24]. Additionally, excessive tillage results in $17 \%$ decline in SOM content within four months. Similar study in Australia also indicated that excessive tillage, insufficient fallowing and burning of crop residues are the major reasons for SOM decline during long-term conventional sugar cane cropping practices [4]. Moreover, the geographical location of Wonji plantation $\left(8^{\circ} 31^{\prime} \mathrm{N}\right.$; near equator) might also have contributed to the observed differences. As the area is associated with high temperatures and humidity, the dynamics of SOM could be much higher than in countries like Australia $\left(29^{\circ} \mathrm{S}-46.5^{\circ} \mathrm{S}\right)$ and Mexico $\left(23^{\circ} \mathrm{N}\right)$ where the temperature is relatively mild. This is because of, as Sanchez and Logan [25] indicated, in tropical countries SOM decomposition rates could be up to five times higher than in temperate regions $[26,27]$.

\section{The main macronutrients}

Total N, P Olsen and exchangeable K contents of the cultivated land were $56 \%, 84 \%$ and $81 \%$ lower than the virgin land at $0 \mathrm{~cm}-30$ $\mathrm{cm}$ depth (Figure 4). The results suggest that there was depletion in the main macronutrients. Unless supplied as organic or inorganic fertilizers, the depletion of these macronutrients can cause substantial yield losses [8].

This observation was in agreement with those of Wood [28] Van Antwerpen and Meyer [2] Hartemink and Wood [15] and Hartemink [27] who reported that uncultivated land had higher levels of total $\mathrm{N}$, available $\mathrm{P}$ and exchangeable $\mathrm{K}$ than cultivated land. The extent of degradation observed in our case was, however, much higher as compared to other countries. In Mexican fluvisols, after 30 years of sugar cane monoculture the $\mathrm{N}, \mathrm{P}$, and $\mathrm{K}$ contents of cultivated land was $14 \%, 43 \%$ and $-5 \%$ lower than uncultivated land, respectively [23].
The significantly lower N, P and $\mathrm{K}$ contents of the cultivated soil than the virgin land (Figure 4) could be partly attributed to high nutrient removal by the cane itself and the lack of replenishment [27]. The practice of pre-harvest cane burning might also have played a role as it can cause $70 \%-95 \%$ loss of the dry matter and $\mathrm{N}$ from the system [28]. The finding of Alemayehu [24] also indicated that in Wonji plantation up on harvesting 120 ton/ha sugar cane about $66 \mathrm{~kg}$ $\mathrm{N} / \mathrm{ha}$ is lost due to burning. Moreover, the continued decomposition of mineralizeable soil $\mathrm{C}$ and $\mathrm{N}$, which is favored by the warm humid climate of the area, excessive tillage and leaching of cations could also be possible causes for the observed differences [29].

At $30 \mathrm{~cm}-60 \mathrm{~cm}$ depth, total $\mathrm{N}, \mathrm{P}$ Olsen and exchangeable $\mathrm{K}$ contents of the cultivated land were $28 \%, 60 \%$ and $81 \%$ lower than the virgin land, respectively (Figure 4). The differences were more pronounced at the soil depth of $0 \mathrm{~cm}-30 \mathrm{~cm}$ than $30 \mathrm{~cm}-60 \mathrm{~cm}$, because sugar cane is shallow rooted and removes little nutrients from deeper soil horizons [30]. Additionally, the extents of the differences between cultivated and virgin lands were much severe in exchangeable $\mathrm{K}$ at both depths (81\%) and available $\mathrm{P}$ at $0 \mathrm{~cm}-30 \mathrm{~cm}$ depth (84\%). This might
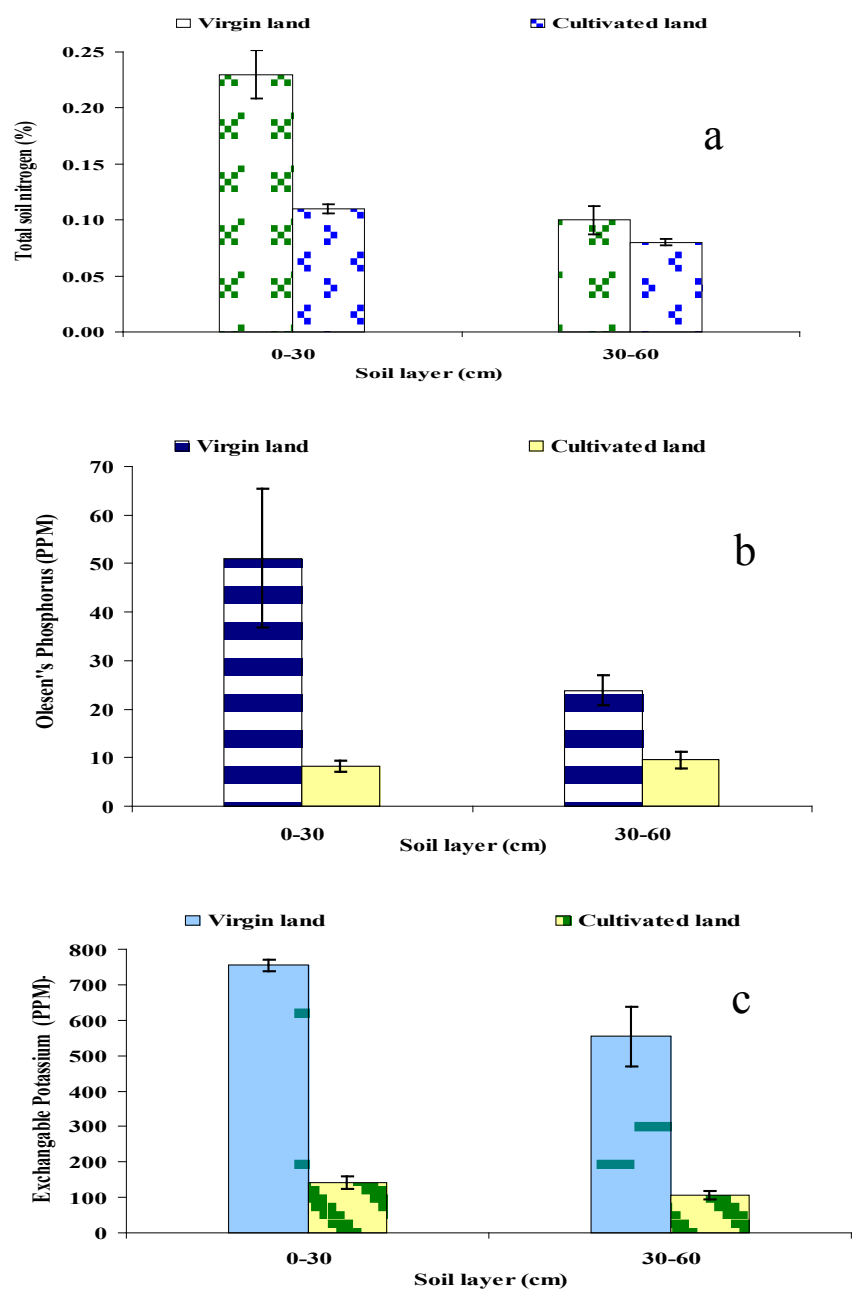

Figure 4: Total $\mathrm{N}$ [a], available $\mathrm{P}$ [b] and exchangeable $\mathrm{K}$ [c] contents of soils at Wonji sugar cane plantation sampled from land areas under conventional cropping practices for 50 years and adjacent lands that were never cultivated [virgin] at $0 \mathrm{~cm}-30 \mathrm{~cm}$ and $30 \mathrm{~cm}-60 \mathrm{~cm}$ depths [means of five sampling sites]. Means of virgin and cultivated lands are significantly different at $\mathrm{P}<0.01$ Vertical bars indicate \pm SEM [standard error of mean]. 
be associated with the fact that no $\mathrm{K}$ and $\mathrm{P}$ fertilizer applications have been practiced since the inception of Wonji plantation. However, the implication of the depletions of these nutrients for the observed yield decline might be of a minor role. This is because of the fact that the application of $\mathrm{N}$ fertilizer in Wonji increases the $\mathrm{P}$ and $\mathrm{K}$ availability in the soil [24]. Moreover the current levels of both P Olsen (8.22 ppm) and exchangeable $\mathrm{K}(142 \mathrm{ppm})$ are not in the range of deficiency. According to Landon [31] sugar cane is among the moderate $\mathrm{P}$ demanding crops where deficiency occurs at less than $7 \mathrm{ppm}$. For K, the critical value ranges from $78 \mathrm{ppm}-125 \mathrm{ppm}$ [32]. The values obtained in this study were above these deficiency levels. This is probably because of the cane burning practices that return $\mathrm{P}$ and $\mathrm{K}$ back to the soil and thus mitigated exhaustion of these nutrients below critical levels [33].

\section{Soil EC}

The soil EC of the cultivated land was $59 \%$ and $66 \%$ lower than the virgin land at $0-30 \mathrm{~cm}$ and $30-60 \mathrm{~cm}$ soil depths, respectively (Figure 5). This implies that the long-term conventional cropping practices resulted in reduction of the soil salt contents. The results were unexpected as the adopted long-term irrigation practices and accumulation of ashes from cane burning would result in development of salinity $[33,34]$. The most likely reason for the lower EC of the cultivated land than the virgin land was the good quality of irrigation water used in the plantation [35], which might leach down the salts. The torrential rainfall which used to occur during a summer season might also contribute to the leaching of salts. Thus, the current level of EC $\left(0.51 \mathrm{mScm}^{-1}\right)$ in Wonji plantation is in the category of optimum range [36].

The soil EC of both the cultivated and virgin land at $30 \mathrm{~cm}-60 \mathrm{~cm}$ depth were much higher than at $0 \mathrm{~cm}-30 \mathrm{~cm}$ depth. This might be attributed to leaching of salts from the top layer of the soil to the lower soil horizon due to the excessive irrigation [37] and rainfall.

\section{Soil pH}

The $\mathrm{pH}$ values of the virgin and the cultivated lands were not significantly different at both depths (Figure 6). The $\mathrm{pH}$ value was expected to decrease, as acid forming fertilizers have been extensively applied in the plantation (96-322 kg urea-N/ha) during the last 50 years. Hartemink and Wood [15] also stated that acid input as ammonium-N fertilizers and alkali removal as uptake of ammonium- $\mathrm{N}$ by the plant can result in acidification of the soil. Moreover, considerable removal of bases with the harvested sugar cane and the leaching of cations can also play a role in reduction of soil $\mathrm{pH}[38,39]$.

Unlike Wonji plantation, there was a decline in the soil $\mathrm{pH}$ in other sugar cane producing countries. For instance in Papua New Guinea, Hartemink et al. [22] reported an $11 \%$ decline during 18 years sugar cane production while in Australia, Moody and Aitken [38] reported $18 \%$ drop during 15 years cultivation. Masilaca et al. [40] also observed $14.4 \%$ drops in soil $\mathrm{pH}$ within 5 years production in Fiji. The invariable $\mathrm{pH}$ observed in Wonji plantation may be ascribed to the method of irrigation and the type of the soil in the study area. In the plantation, the major method of irrigation is blocked end furrow system. As the soil type of the plantation is heavy clay, this type of irrigation often resulted in severe water logging problem. According to Sun [41] water logging can increase the $\mathrm{pH}$ level of a soil through fast depletion of $\mathrm{O}_{2}$ that leads to anaerobic conditions with concomitant reduction in Eh (redox potential). Reduction reactions use mainly $\mathrm{H}^{+}$and thus result in rises in $\mathrm{pH}$. On the contrary, these scenarios might not have occurred in the New Guinea, Australia and Fiji studies, cited before, where the sugar cane is mainly rainfed.

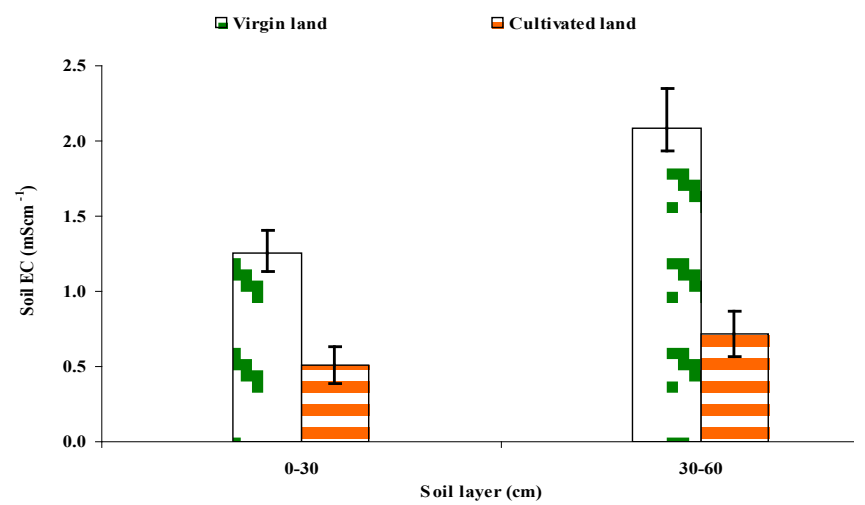

Figure 5: $\mathrm{EC}\left[\mathrm{mScm}^{-1}\right]$ of soils at Wonji sugar cane plantation sampled from land areas under conventional cropping practices for 50 years and adjacent lands that were never cultivated [virgin] at $0 \mathrm{~cm}-30 \mathrm{~cm}$ and $30 \mathrm{~cm}-60 \mathrm{~cm}$ depths [means of five sampling sites]. Means of virgin and cultivated lands are significantly different at $P<0.01$. Vertical bars indicate \pm SEM [standard error of mean].

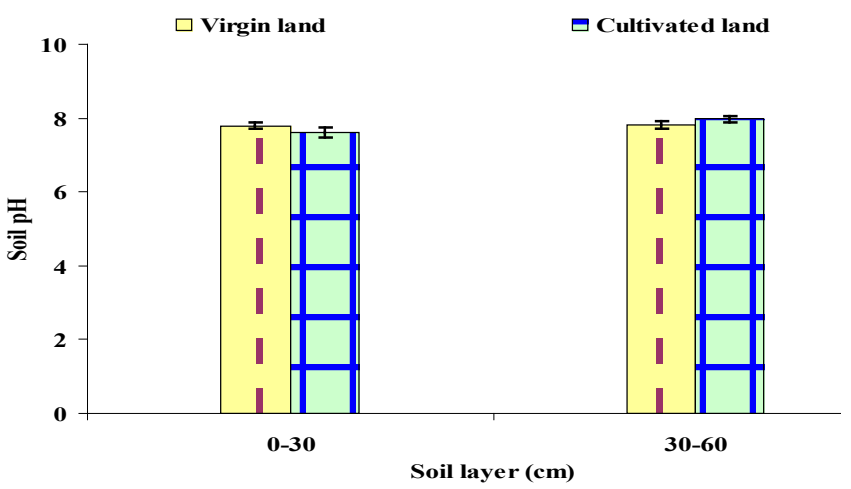

Figure 6: $\mathrm{pH}$ of soils at Wonji sugar cane plantation sampled from land areas under conventional cropping practices for 50 years and adjacent lands that were never cultivated [virgin] at $0 \mathrm{~cm}-30 \mathrm{~cm}$ and $30 \mathrm{~cm}-60 \mathrm{~cm}$ depths [means of five sampling sites]. Means of virgin and cultivated lands are not significantly different at $P<0.01$. Vertical bars indicate \pm SEM [standard error of mean].

\section{Conclusion}

The long-term conventional copping practices substantially degraded the major soil quality indicators of Wonji plantation i.e., SOM, total $\mathrm{N}$, available $\mathrm{P}$ and exchangeable $\mathrm{K}$. Nevertheless, the soil $\mathrm{pH}$ and EC were in the optimum range that there are no problems related with soil salinity, alkalinity and acidity. As the soil of Wonji plantation is mainly heavy clay, particularly, the decline in SOM content along with the furrow irrigation system and the excessive traffic of machineries in the sugarcane plantation fields might play a role for the observed yield decline. This could be through exacerbating the detrimental effects of water logging and soil compaction. Thus, improving the SOM content could be essential in partly arresting the declining yield. Moreover an extensive multidisciplinary campaign should be further continued in order to fully identify, understand and manage the problem of soil quality deterioration.

\section{Acknowledgements}

I would like to thank Ethiopian Sugar Development Agency for covering all the expenses of this research work. My heartfelt thanks is also forwarded to Netherland fellowship program for grating me a fund to attend my study in the Netherlands. Above all praise be to God for all his assistances. 
Citation: Alemayehu D, Lantinga E (2016) Impact of Long-Term Conventional Cropping Practices on Some Soil Quality Indicators at Ethiopian Wonji Sugarcane Plantation. Adv Crop Sci Tech 4: 224. doi:10.4172/2329-8863.1000224

Page 5 of 5

\section{References}

1. Solomon S, Grewal SS, Rui Li Y, Magarey RC, Rao GP (2006) Sugar cane: Production management and agro-industrial imperatives. International Book Distribution Co, India.

2. Van Antwerpen R, Meyer JH (1996) Soil degradation under sugarcane cultivation in northern KwaZulu-Natal. Proceedings of South African Sugar Technologists Association 70: 29-33.

3. Bell MJ, Garside AL, Halpin NV, Berthelsen JE (2001) Yield responses to breaking the sugarcane monoculture. In: Rowe B (eds.) Proceedings of 10th Agronomy Conference, Australian society of Agronomy.

4. Garside AL, Bell MJ, Robotham BG, Magarey RC, Stirling GR (2005) Managing yield decline in sugarcane cropping systems. International Sugar Journal 107: 16-26.

5. Fauconnier R (1993) Sugarcane, The tropical agriculturalist, Macmillan Press Ltd, London.

6. Verma RS (2004) Sugar cane production technology in India. Lucknow, International book distributing co.

7. De Wit CT (1992) Resource use efficiency in agriculture. Agricultural Systems 40: $125-151$

8. Schjønning P, Elmholt S, Christensen BT (2004) Managing soil quality: Challenges in modern agriculture. In: Schjønning P, Elmholt S, Christensen BT (eds.) Soil Quality Management-Concepts and Terms, CABI Publishing, Danish Institute of Agricultural Sciences, Department of Agroecology, Tjele, Denmark, pp: 1-12.

9. Lal R (2009) Soil degradation as a reason for inadequate human nutrition. Food Security 1: 45-57.

10. Bramley RV, Ellis N, Nable RO, Garside AL (1996) Changes in soil chemical properties under long-term sugar cane monoculture and their possible role in sugar yield decline. Australian Journal of Soil Research 34: 967-984.

11. Davies J (1998) The causes and consequences of cane burning in Fiji's sugar belt. The Journal of Pacific Studies, 22: 1-25.

12. Morris DR, Tai PY (2004) Water table effects on sugarcane root and shoo development. American Society of Sugar Cane Technologists 24: 41-59.

13. Pankhurst CE, Magarey RC, Stirling GR, Blair BL, Bell MJ, et al. (2003) Management practices to improve soil health and reduce the effects of detrimental soil biota associated with yield decline of sugarcane in Queensland, Australia. Soil and Tillage Research 72: 125-137.

14. Girma MM, Awulachew SB (2007) Irrigation practices in Ethiopia: Characteristics of selected irrigation schemes. Colombo, Sri Lanka: International Water Management Institute, p: 80.

15. Hartemink AE, Wood AW (1998) Sustainable land management in the tropics: the case of sugarcane plantations. Proceeding of the 16th International Congress of Soil Science, Montpellier.

16. Bremner JM, Mulvaney CS (1982) Nitrogen total. In: Page AL, Miller RH Keeney DR (eds.) Methods of Soil Analysis. II. Chemical and Microbiological Properties. (2nd edn), pp: 595-624.

17. Walkley A, Black IA (1934) An examination of the Degtjareff method for determining organic carbon in soils: Effect of variations in digestion conditions and of inorganic soil constituents. Soil Sci 63: 251-263.

18. Olsen SR, Cole CV, Watanable FS, Dean LA (1954) Estimation of available phosphorous in soil by extraction with sodium bicarbonate. United States Agricultural Circ., USA.

19. Morgan MF (1941) Chemical diagnosis by the universal soil testing system. Connecticut Agricultural Experimental Station, Bulletin, p: 450.

20. Reeves DW (1997) The role of SOM in maintaining soil quality in continuous cropping systems. Soil Tillage Research 43: 131-167.

21. Alaban RA, Barredo FC, Aguirre AL (1990) An assessment of some indicators and determinants of farm productivity and soil fertility in the VMC district: trends, associations, interactions 1969-1990. Proceedings of the Philippine Sugar Technologists, pp: 64-83.

22. Hartemink AE, Nero J, Ngere O, Kuniata LS (1998) Changes in soil properties a Ramu Sugar Plantation 1979-1996. Papua New Guinea Journal of Agriculture, Forestry and Fisheries 41: 65-78.
23. Naranjo de L, Salgado-Garciá FS, Lagunes-Espinoza LC, Carrillo-Avila E, Palma-López DJ (2006) Changes in the properties of a Mexican Fluviso following 30 years of sugarcane cultivation. Soil Tillage Research 88: 160-167.

24. Alemayehu D (2010) Sustainable Sugarcane Production in Ethiopia, Exploring Challenges and Opportunities. Biological Farming System Group. MSc Thesis. Wageningen University, The Netherlands.

25. Sanchez PA, Logan TJ (1992) Myths and science about the chemistry and fertility of soils in the tropics. In: Lal R, Sanchez PA (eds.) Myths and science of soil of the tropics. SSSA Spec. Publ. 29. SSSA, Madison, WI, USA, pp: 35-46.

26. Wood AW (1985) Soil degradation and management under intensive sugarcane cultivation in North Queensland. Soil Use and Management 1: 120-124.

27. Hartemink AE (2001) Sustainable land management at Ramu sugar: Assessment and requirements. In: Bourke RM, Allen MG, Salisbury JG (eds.) Food Security in Papua New Guinea, ACIAR Proceedings no. 99, Canberra, pp: 344-364.

28. Thorburn PJR, Van A, Meyer JH, Bezuidenhout CN (2002) The impact of trash management on soil carbon and $\mathrm{N}$ : I Modelling long-term experimental results in the South African sugar industry. Proceedings of the South African Sugar Technologists Association 76: 260-268.

29. Brown S, Lugo A (1990) Effects of forest clearing and succession on the carbon and $\mathrm{N}$ content of soils in Puerto Rico and US Virgin Islands. Plant Soil 124 $53-64$.

30. Smith DM, Inman-Bamber NG, Thorburn PJ (2005) Growth and function of the sugarcane root system. Field Crops Research 92: 169-183.

31. Landon JR (1984) Booker Tropical Soil Manual: A hand book for soil survey and agricultural land evaluation in the tropics. Longman. New York, USA.

32. Orlando FJ (1989) Potassium nutrition of sugarcane. In: Munson RE (eds.) Potassium in Agriculture. American Society of Agronomy, Madison, Wisconsin USA, pp: 1045-1076.

33. Khan MJ, Qasim M (2008) Integrated use of boiler ash as organic fertilizer and soil conditioner with NPK in calcareous soil. Songklanakarin Journal of Science and Technology 30: 281-289.

34. Smedema LK, Shiati K (2002) Irrigation and salinity: A perspective review of the salinity hazards of irrigation development in the arid zone. Irrigation and Drainage Systems 16: 161-174

35. Girma A (2006) Evaluation of irrigation water quality in the Ethiopian sugar estates. Ethiopian sugar industries support Centre Co, Research report, Wonji.

36. Yuste MP, Gostincar J (1999) Handbook of agriculture. Marcel Dekker, New York, USA.

37. Habib D, Girma T (2006) Evaluation of irrigation interval and irritation efficiencies in the Ethiopian sugar estates. Research report. Wonji.

38. Moody PW, Aitken RL (1995) Soil acidification and lime use in some agricultura systems in Queensland. In: Date RA (eds.). Plant soil interactions at low pH, Kluwer Academic, Dordrecht, pp: 749-752.

39. Kahlown MA, Ashraf M, Zia-ul-Haq M (2005) Effect of shallow groundwater table on crop water requirements and crop yields. Agricultural Water Management 76: 24-35.

40. Masilaca AS, Prasad RA, Morrison RJ (1986) The impact of sugarcane cultivation on three Oxisols from Vanua Levu, Fiji. Tropical Agriculture 63: 325330

41. Sun L, Chen S, Chao L, Sun T (2007) Effects of flooding on changes in Eh, pH and speciation of cadmium and lead in contaminated soil. Bull Environ Contam Toxicol 79: 514-518.

Citation: Alemayehu D, Lantinga E (2016) Impact of Long-Term Conventiona Cropping Practices on Some Soil Quality Indicators at Ethiopian Wonji Sugarcane Plantation. Adv Crop Sci Tech 4: 224. doi:10.4172/2329 8863.1000224 